June 2019

\title{
The More You Know, the More You Owe
}

Megan Price

San Jose State University, mmeprice@protonmail.com

Follow this and additional works at: https://scholarworks.sjsu.edu/ischoolsrj

Part of the Accessibility Commons, Archival Science Commons, Cataloging and Metadata Commons, Collection Development and Management Commons, Gender Equity in Education Commons, Information Literacy Commons, Museum Studies Commons, Online and Distance Education Commons, Scholarly Communication Commons, and the Scholarly Publishing Commons

\section{Acknowledgements}

\section{Recommended Citation}

Price, M. (2019). The More You Know, the More You Owe. School of Information Student Research Journal, 9(1). https://doi.org/10.31979/2575-2499.090101 Retrieved from https://scholarworks.sjsu.edu/ ischoolsrj/vol9/iss1/1

This article is brought to you by the open access Journals at SJSU ScholarWorks. It has been accepted for inclusion in School of Information Student Research Journal by an authorized administrator of SJSU ScholarWorks. For more information, please contact scholarworks@sjsu.edu. 


\title{
The More You Know, the More You Owe
}

\section{Keywords}

editorial, academic journal, lis research, literacy, public libraries, accessibility, archives

\section{Acknowledgements}

\author{
About Author \\ Megan Price (mmeprice.org) is a recent graduate of SJSU iSchool's MLIS program. She currently lives in \\ Europe where she is seeking to do good work with good people at the intersection of culture, arts, and \\ information
}




\section{The More You Know, the More You Owe}

YA author, Luis J. Rodriguez exemplifies his quote, "The more you know, the more you owe," through his work as a leader and activist. He employs his personal experience and his professional success to foster growth, connection, and empowerment in his community. Like Rodriguez, the authors in this, the SRJ's 17th issue, identify field-wide opportunities for LIS professionals to do the same with patrons in their communities, moving outside of familiar or engrained roles toward active equity work.

As a youth advocate, parent of a teen-aged girl, and former high school educator, I gratefully welcome this issue's invited contribution by Dr. Mary Ann Harlan, SJSU iSchool Associate Professor and Teacher Librarian Program Coordinator. In this excerpt from her new book, The Girl-Positive Library: Inspiring Confidence, Creativity, and Curiosity in Young Women, Dr. Harlan reveals that YA fiction serves not only as an information source for self and world discovery, but as both a perpetrator and challenger of the norms and expectations of young women. Youth services librarians, with this awareness, can suggest books and provide library programming that guides their patrons toward new archetypes of girl heroines.

Current SRJ editor Channon Arabit's evidence summary evaluates a 2015 study of the accessibility of two content management systems, RELX's bepress, and OCLC's CONTENTdm for users with visual impairments. This study provides data in support of increased accessibility measures in digital information, research, and archive platforms.

Author Suzanne S. LaPierre's article confirms the positive effects of artist and archivist collaboration, and how it evolves archival collections and collection processes, increasing their diversity, accuracy, access and availability. This work broadens the audience's involvement and draws attention to a wider range of collections for use and exploration.

Author Georgia Westbrook reviews Eric Klinenberg's Palaces for the People: How Social Infrastructure Can Help Fight Inequality, Polarization, and the Decline of Civic Life. Westbrook confirms Klinenberg's assertion that public libraries are essential to communities, responsible for providing needed services, information access, and community spaces for members from all facets of society to gather, explore ideas, and expand knowledge.

With service to others as the foundation of our work, we can use our positions as community leaders to keep equity and access at the forefront of professional conversations and strengthen the voice of the field so that we can continue to empower others. We must work to ensure that all are welcomed in our 
institutions, and to support each patron's right to live a life of liberty and pursue happiness.

\section{Acknowledgements}

It has been a great honor to serve in as Editor-in-Chief of $S R J$. As I leave my position and pass the torch to the ever-capable and dynamic Greta Snyder, I want to thank the team that made this issue possible: Stephanie Akau, Channon Arabit, Claire Goldstein, Terry Shiavone, Tayci Stallings, and Havilah Steinman. A special thank you to our Managing Editor, Rachel Greggs, who managed an onslaught of submissions this semester, and who organized and facilitated their rigorous and detailed review. Rachel has been an excellent thought partner, an advocate for all voices, and a model colleague. My deepest thanks to Dr. Anthony Bernier for his guidance and unending support of the journal and its mission. And finally, to our Editorial Board, led by iSchool Director Dr. Sandra Hirsh and Associate Director Dr. Linda Main, and to all the faculty and staff at the iSchool, we thank you for your continued support. 